\title{
Choice, needs or equality? Discursive struggles about defining home care for older people in Sweden
}

\author{
Elin Peterson ${ }^{1 \star}$ (D) and Helene Brodin ${ }^{1}$ \\ ${ }^{1}$ Department of Social Work, Stockholm University, Stockholm, Sweden \\ ${ }^{*}$ Corresponding author. Email: elin.peterson@socarb.su.se
}

(Accepted 22 January 2021; first published online 26 February 2021)

\begin{abstract}
Focusing on Swedish home care for older people, this article explores the discursive (re) production of home care as an institution. Equality and universal service provision have been described as defining features of the Nordic care regime. At the same time, Nordic research has highlighted a shift in social care policy, from a focus on universalism and egalitarian ideals towards a focus on freedom of choice, diversity and individualised services. This article takes as a starting point that home care for older people is formed by different and potentially conflicting ideas. We understand home care as a contested formation and define institutional change in terms of ongoing discursive struggles. The analysis draws on qualitative semi-structured interviews with key informants, including politicians, local authority officials and representatives of interest organisations. Informants were engaged in policy making, implementation or advocacy related to care for older people. We examine the meanings attached to home care for older people and the analysis reveals three different discourses - on choice, needs and equality. By comparing and contrasting discourses, we reveal silences, conflicts and tensions, and highlight the politics involved in (re)creating home care as an institution.
\end{abstract}

Keywords: home care; older people; institutions; Sweden; discourses; choice; needs; equality

\section{Introduction}

Focusing on Swedish home care for older people, this article explores the discursive (re)production of home care as an institution. Equality and universal service provision have been described as defining features of the Nordic care regime. At the same time, Nordic care research has highlighted a shift in social care policy, away from egalitarian ideals and towards a focus on freedom of choice, diversity and individualised services. This article takes as a starting point that home care for older people is formed by different and potentially conflicting ideas. Our analytical approach understands home care as a contested formation and defines

(C) The Author(s), 2021. Published by Cambridge University Press. This is an Open Access article, distributed under the terms of the Creative Commons Attribution licence (http://creativecommons.org/licenses/by/4.0/), which permits unrestricted re-use, distribution, and reproduction in any medium, provided the original work is properly cited. 
institutional change in terms of ongoing discursive struggles. The analysis draws on qualitative interviews with key informants, including politicians, local authority officials and representatives of interest organisations. Informants were all actively engaged in policy making, implementation or advocacy related to care for older people. By focusing on the articulation of meanings attached to home care for older people, we also reveal different ideas about older people, (good) care and home care as a system. In addition, the study examines how the accounts legitimise certain normative ideas about home care, while silencing other possible meanings.

\section{Swedish home care}

When the idea of universal service provision was brought into public political discourse by the Social Democrats in Sweden at the beginning of the 20th century, it was closely linked to the promotion of equality and social solidarity (Anttonen, 2005). Home care services were introduced in the 1950s and soon became used by all social groups, as these services were affordable for the lower socio-economic classes and attractive enough to be preferred by the middle class. Home care developed into an individualised alternative to the more standardised forms of care available in old-age homes and residential care. The principle of ageing-in-place, introduced in public policy in 1957, was formulated as a fundamental goal in the Social Services Act in 1982 (Brodin, 2017).

The Social Services Act guarantees all older people a general right to assistance and services should ensure users a 'reasonable standard of living'. Children and relatives have no legal responsibility to care for frail older people. While elder-care is governed through legislation, state subsidies and supervision at the national level, the regional county councils are responsible for hospital care and the major part of health care. The municipalities are legally obliged to fund and provide social services, including home care. ${ }^{1}$ The municipal councils adopt budgets and levy taxes, establish goals and guidelines for needs assessment, and decide on eligibility criteria and user fees ${ }^{2}$ (Szebehely and Trydegård, 2012). Care managers appointed by the local authorities decide on the distribution of care services for older adults through needs assessment.

Overall, there is a tension between the principle of universalism and equality set out on national legislation, and that of local self-determination. The Social Services Act is a goal-oriented framework law and does not confer specific rights. Additionally, the principle of local self-government gives municipalities extensive freedom to interpret the meaning of 'reasonable standard of living'. Local politicians and senior managers often emphasise the need to stick to the municipal budget and restrictive eligibility guidelines. Further, local politicians have to prioritise between different welfare areas and increased legal ambitions in child care and disability care can mean that older people's care needs are given lower priority than before, within relatively fixed resource constraints (Szebehely and Trydegård, 2012).

The Act on System of Choice (LOV) from 2009 regulates the conditions that apply when a municipality decides to allow older persons to choose their provider of care services (i.e. the organisation, not the care worker) from a list of approved providers. All legally recognised organisations can apply for approval and there is no limit on the number of providers (Erlandsson et al., 2013). The reform 
anticipated that older adults' right to choose their care provider - and change if not satisfied - would strengthen users' voice and improve service quality through competition. Currently, 162 out of 290 Swedish municipalities have implemented choice in publicly funded home care (SKR, 2019).

There have been salient changes in the Swedish welfare provider mix since the turn of the millennium as private welfare provision has increased strongly, particularly for-profit. The non-profit share of paid employees in social services has been small but stable at about 3 per cent, while for-profit providers increased their share from 15 to 25 per cent between 2007 and 2013 (Sivesind, 2017: 46-47). However, there is great local variation. As for home care services, private provision constitutes 59 per cent of the service hours in the municipality of Stockholm while, in the whole country, privately provided service hours constitute 23 per cent (National Board of Health and Welfare (NBHW), 2019a).

The Act on Tax Deduction on Domestic Services ${ }^{3}$ (in Swedish called RUT) from 2007 does not form part of formal elder-care policies, but older people can use RUT services as an alternative to home care. They can also use the tax deduction to 'top up' their needs-assessed care. Only private home care providers are allowed to offer users additional tax-deductible services (Erlandsson et al., 2013). Because user fees are both income-related and dependent on the number of hours of help, for older people with higher pensions and smaller care needs, privately purchased domestic services can be cheaper than needs-assessed home care. In recent years, use of the tax deduction has increased among older people in general, but more among older people with higher incomes (Ulmanen and Szebehely, 2015).

The free choice reform and the tax deduction were promoted by and adopted during a period of centre-right governments (2006-2014). The left parties have been critical, but coalition governments of the Social Democrats and Green Party (2014-) have not made any major reforms. Additionally, the Social Democratic Party has only weakly contested the expansion of for-profit care providers that has also occurred during Social Democratic rule (Meagher and Szebehely, 2019).

Currently, 8 per cent of the population aged $65+$ and 22 per cent of people aged $80+$ receive home care services (NBHW, 2019b), compared to 16 and 34 per cent, respectively, in 1980 (Szebehely and Trydegård, 2012: 301). Declining coverage is a consequence of increased targeting of those with the greatest care needs. A smaller proportion of older people receive more intensive care in their homes, and even severely ill older adults receive home care instead of assistance in a nursing home (Brodin, 2017). This relates to the significant decline in residential care; the number of beds was reduced by one-quarter between 2000 and 2012 (Ulmanen and Szebehely, 2015). Concurrently, home care services have changed from mainly including help with domestic tasks (e.g. cleaning) to involve significant help with personal care and nursing components. These changes in Swedish eldercare are not the result of any national reforms aimed at reducing coverage (Szebehely and Trydegård, 2012). Nevertheless, the question of 'sustainable' financing of welfare services has been on the political agenda for some time, including debates about increasing private financing (e.g. through RUT) and excluding cleaning from publicly funded home care (Meagher and Szebehely, 2010).

In this context, it can be noted that 15 per cent of women aged $65+$ and 7 per cent of men 65+ have an income that is below the limit of relative poverty (i.e. lower 
than 50 per cent of the country's median income). The differences in relative poverty rates between older women and older men in Sweden are among the greatest in the Organisation for Economic Co-operation and Development. Foreign-born and the oldest old are categories that have a particularly high risk of poverty (NBHW, 2020: 19). Further, an increasing proportion of older people have an immigrant background. Migration to Sweden has followed several waves, from labour force migration mainly coming from European countries (e.g. Finland, Greece and former Yugoslavia) in the 1960s and 1970s, to refugees from non-European countries and family reunions in more recent decades (Aldén and Hammarstedt, 2014). Since the year 2000, the proportion of foreign-born persons in the population has increased from 11 per cent to close to 20 per cent (Ministry of Finance, 2020: 483). Choice systems have been promoted as a way to adapt to ethnic diversity among the older population, enabling small care companies with specific linguistic and cultural profiles to enter the market (Brodin, 2017). Swedish elder-care also relies increasingly on foreign-born care workers. Currently, 32 per cent of the care workers are foreign-born, of whom two-thirds were born in Asia, Africa or Latin America (Statistics Sweden, 2019). In Stockholm and other bigger cities, the proportion of foreign-born care workers is much higher than the national average.

\section{Research on social care and choice systems in Nordic contexts}

Equality has often been highlighted as a defining feature of the Nordic universalistic care regime, connected to policies that reduce both class and gender inequalities (Szebehely and Meagher, 2018). Nevertheless, the introduction of choice systems in the Nordic countries has often been framed by their advocates as the solution to the 'problem' of equality, referring to publicly provided, uniform, standardised and inflexible care services (Moberg, 2017; Dunér et al., 2019). Both Nordic and Anglo-Saxon scholars have linked the introduction of choice to a policy discourse on individualised care, diversity of services and empowerment of users (e.g. Barnes and Prior, 1995; Fotaki and Boyd, 2005; Clarke, 2006; Vabø, 2006; Glendinning, 2008; Brennan et al., 2012; Moberg et al., 2016). Likewise, choice policies have been situated within the context of New Public Management (NPM), the global reform agenda that promotes the incorporation of market ideas and practices in the organisation and delivery of public services.

Studies have extensively investigated the effects, problems and limitations of choice reforms. Research focusing on choice in practice criticises the assumption of the 'rational' care consumer and underlines that older people face great impediments in making informed choices (e.g. Glendinning, 2008; Meinow et al., 2011; Moberg et al., 2016; Vamstad, 2016; Dunér et al., 2019). Those with the greatest care needs are most dependent on choosing a provider that will offer good care, but have the least capacity to do so (Meinow et al., 2011). Social inequalities shape the practice of choice and people who already belong to privileged groups (e.g. higher educated, native-born) are more likely to benefit (Glendinning, 2008; Brennan et al., 2012; Brodin, 2017).

Nordic research has questioned the assumption of user empowerment in various ways. In quasi-markets for home care, purchasing power resides with local 
authorities, often restrained by overarching cost concerns (Vabø, 2006). Users can choose their care provider, but are not entitled to choose the services and user 'voice' is not necessarily strengthened. While choice policies have constructed the possibility of 'exit' as the key to user influence, studies indicate that older people seldom change care providers (Vamstad, 2016). Care research generally highlights the relational nature of care, and the significance of time and context. Accordingly, empowerment of older users requires empowering relationships with care workers in daily life (Vabø and Szebehely, 2012). However, studies indicate that choice models generate control systems and detailed regulation of care work, which limit care workers' discretion and capacity to attend to individual needs and wishes (Vabø, 2006; Brennan et al., 2012; Rostgaard, 2012; Vabø and Szebehely, 2012; Erlandsson et al., 2013).

Research has also indicated that provider choice together with tax deductions for domestic services risk reinforcing structural inequalities (Szebehely and Trydegård, 2012; Vabø and Szebehely, 2012; Ulmanen and Szebehely, 2015; Moberg, 2017; Szebehely and Meagher, 2018). If those who can afford it get more and better care while the rest receive meagre basic services, universalism is threatened.

The role of discourses in institutional change has been widely explored in the field of social policy and public policy more generally (e.g. Schmidt, 2008; Bacchi and Rönnblom, 2014; Béland, 2016; Béland and Powell, 2016). In this article, we draw on Bacchi and Rönnblom (2014) who define institutions not in terms of fixed and discrete entities but in terms of open-ended assemblages. Institutions are, hence, contested formations, riddled with tensions and constituted by and through a multiplicity of discourses. In this vein, and in line with Vabø (2015), we see home care as constituted though 'discursive struggles', whereby various actors 'create, maintain and disrupt institutions in accordance with their particular frames of meaning' (Vabø, 2015: 243). This approach problematises the understanding - underpinning much care research - of home care as a given entity. Previous studies have shown how discourses on choice, marketisation and NPM shape health and social care in Sweden and other Nordic countries (Andersson and Kvist, 2015; Vabø, 2015; Burau et al., 2016; Nilsson et al., 2018; Lindberg and Lundgren, 2019). However, studies have not yet analysed the discursive struggles involved in the formation of home care as an institution in the context of the implementation of choice.

\section{Methods and analytical framework}

Our qualitative analysis is based on 18 semi-structured key informant interviews conducted in 2017 with local authority officials, politicians and representatives of interest organisations (Table 1). The study was approved by the Regional Ethical Vetting Board in Stockholm. Using purposive selection, the informants included were all actively engaged in questions related to elder-care, by means of policy making, implementation or advocacy. Hence, they could be expected to provide rich and relevant accounts of home care. Selection aimed to capture diversity of standpoints and experiences, and all relevant stakeholder positions were included, above the level of needs assessors. Many of the informants were active in Stockholm. Stockholm adopted a choice system in 2002 and has a large number of private 
Table 1. Type of organisation and number of interviews

\begin{tabular}{lc}
\hline Type of organisation & Number of interviews \\
\hline Public authority (Stockholm) & 6 \\
\hline Political party (Stockholm) & 4 \\
\hline Interest organisation (national and local) & 8 \\
\hline Total & 18 \\
\hline
\end{tabular}

providers, mainly for-profit. Further, political rule in Stockholm has mirrored the political majority at the national level from 2006 to 2018. Together these aspects make Stockholm an interesting case for studying home care in the context of the implementation of choice.

The six local authority officials held positions of responsibility in elder-care in Stockholm; two were situated in city districts with high average socio-economic status in the city centre, three in city districts with lower average socio-economic status in the outskirts. One was responsible for procurement and oversight at the citylevel. Four local politicians were interviewed: two belonging to the left-green coalition in government at the time and two from the centre-right opposition (here referred to as 'left-wing' and 'right-wing', respectively). All four were members of Stockholm's Elderly Committee, responsible for co-ordinating and developing elder-care, and one held the position of Elder-care Commissioner. Selected interest organisations included those considered influential in public debates on elder-care in Sweden: the Association of Private Care Providers (Vårdföretagarna), the Association of Non-profit Health and Social Service Providers (Famna), the Swedish Association of Local Authorities and Regions (SKR), which is an employer organisation for regional and local authorities, and the Municipal Workers Union (Kommunal), which organises home care workers. We also included the Pensioner's Advisory Council of Stockholm, and the pensioners' organisations PRO (one interview with national-level representative and one with local representative) and SPF (one interview with two regional representatives). These two pensioners' organisations are the largest in Sweden, together representing about 590,000 senior citizens. PRO is associated with left-wing political ideas and SPF with right-wing.

The authors conducted all interviews. The interviews analysed here formed part of a bigger study on the implementation of choice in home care. The interviews followed a semi-structured topic guide organised around different themes. In this article, we focus on the responses to questions related to the following themes: (a) the role of the organisation and the informant's role within it; (b) the implementation of choice in home care; (c) home care service delivery and the organisation of care work; and (d) older adults' needs and good care. The interviews were transcribed, coded, and thematically analysed and compared. Both authors conducted a close reading of all the transcripts. Thereafter, we coded the data according to meanings attributed to home care. In the process of coding our data, we identified three central themes and these structure the presentation of the findings: 'choice', 'needs' and 'equality'. Codes that reflected different representations of 
older people, of (good) care and of the home care system, were organised in relation to the central themes. To validate our analysis, we contrasted the codes and themes we had identified in the data with each other and we continuously returned to our interview data during the iterative analytical process.

The analysis was guided by discourse analysis. As previously outlined, we see the institution of home care as constituted in and by a multiplicity of discourses and, hence, as a contested formation. In the course of analysing our data, it became clear that the informants' accounts involved different ideas of what home care is, and what future home care should be about. As argued by Laclau and Mouffe (2001), any order can be seen as a result of a struggle about what constitutes the reality of a situation. Following from this, our analysis takes the existence of discursive struggles, tension and conflict as the point of departure. We explore the processes whereby meanings are attributed to home care, and by so doing, we also analyse how other possible meanings are excluded and silenced. Our coding identified three central themes around which meanings were organised. In Laclau and Mouffe's terminology, these themes - choice, needs and equality - are understood as 'nodal points', occupying central positions in discourse. At the same time, their meanings are not given. Choice, needs and equality are also 'empty signifiers', filled with meaning through the association with different subject positions, normative assumptions and concepts. The analytical approach assumes that subjects are produced in discourse and we explore the subject positions made available for older people with home care in the different discourses. In line with Bacchi (2005), our analysis does not attempt to reveal underlying interests or motivations of actors, neither do we attempt to reveal how actors strategically 'use' discourse for their own purposes. To illustrate findings, quotes in the paper have been translated from Swedish to English.

\section{Findings: the discursive (re)production of home care}

In the following, we explore the different discourses that co-exist and compete in constructing home care as an institution. Additionally, the analysis pays attention to tensions within the discourses. The discourses should not be understood as clearly separate but as overlapping, and each informant's account typically entailed at least two of the discourses. This implies a certain incoherence in the accounts, with the shift between different discourses often relating to the questions we asked. While the informants generally articulated more than one discourse, we present key bearers of each discourse, identified by scrutinising whether the majority of the answers were related to choice, needs or equality.

\section{The choice discourse}

The informants who related most questions in the interviews to a choice discourse were the local authority officials, and the informants who represented the Swedish Association of Local Authorities and Regions, the Organisation of Private Care Providers, the senior citizens' organisation SPF and right-wing political parties. That the local authority officials tended to articulate a choice discourse may 
indicate the strength of this discourse in the local context of Stockholm. LOV was the main legal reference in this discourse.

When the informants were asked questions about their perceptions of the implementation of choice in home care, the answers often echoed the market-oriented arguments evinced in support of LOV. In this context, the local authority officials described the home care system as equivalent to the home care market. One described home care in the following terms: 'it's well established, it's a wellfunctioning market'. In other accounts, the process of market 'consolidation' was emphasised, assuming (even) better functioning as approaching in the future. The official responsible for procurement underlined that home care is a relatively new sector and that it is natural that there have been some 'problems' due to, for example, lack of business know-how among private home care providers. This informant also stressed that currently the market is 'adjusting'. The implementation of choice in home care was described in terms of innovation and as a win-win situation, with positive effects at the level of the system and the individual. Competition was leading to greater efficiency and diversification of both providers and services. 'Freedom of choice' was represented as an essential value, linked to individual selfdetermination. In this vein, a third local authority official referred to all-encompassing positive effects:

Customer choice has been positive for older people - freedom of choice is good for most people. Competition is positive, the public providers face competition, the needs can be met in different ways; the operations can be run in a better way. (Local authority official)

A key assumption was that choice systems generate good home care. Providers that do not deliver good care will eventually lose their customers as they will not be chosen and, in the end, will eventually disappear. The possibility of 'exit' was often perceived as even more important than the opportunity to choose provider in the first place. One local authority official emphasised that the option to change providers can assure the individual good care:

If you are not happy with the care you get, then you can always change providers, so there are all the possibilities to receive good care. (Local authority official)

Another local authority official emphasised that when the needs assessors follow up the older people, they always ask whether they are 'satisfied or want to change [provider]'. This informant also pointed out the challenge of choosing the 'right' provider.

A dilemma perceived by practically all the informants was that older people with care needs are not, in fact, prone to changing providers. In several interviews, there was a tension between the informants' accounts of how choice in home care generates good care, and their recognition that older people seldom change care providers. At the same time, some informants argued that provider choice increases individual older adults' ability to influence the content of their care in their daily life. For example, one right-wing politician associated provider choice with the opportunity to choose one's care worker, but emphasised the 'feeling' of choice 
and self-determination, and downplayed the fact that things may turn out differently in practice:

It's like I'm deciding, I own the question of who's going to come to my home. Then, maybe it's not always like [that], because of practical reasons and so, but it's a really important feeling, to maintain self-determination in old age. (Politician)

Informants who primarily articulated a choice discourse emphasised the connection between competition, choice systems and diversity of services. They pointed out that in the home care market the diversity of services is reflected in care companies' different 'profiles', and the most recurrent kind mentioned was language profiles. Sometimes language profiles were associated with individual preferences, rather than meeting the needs of older immigrants. One right-wing politician framed language profiles in such terms:

You can change from the home care Södertjänst [public provider in the city centre] to Finnish home care - because you feel they have more 'go' or because you want to speak Finnish. (Politician)

In a similar vein, one local authority official differentiated between basic needs and individual preferences, and argued that the individual preference for a specific language profile is better met in a choice system.

Also, more generally, the implementation of choice was associated with the production of care services tailored to fit the individual preferences of a diverse older population. When 'preferences' were foregrounded, vulnerability and needs were eclipsed from the meaning of care. Further, when asked about what constitutes good care, the informants emphasised that the experience and perception of care is subjective, depending on individual preferences and wishes. Several informants raised examples that dealt with individual habits, such as when to get up in the morning and what to eat and drink. Thereby, older people with home care were represented as relatively autonomous older adults capable of deciding how they want things. For example, one local authority official described good care this way:

It's very individual too. I mean, good care can be that I get to eat caviar sandwiches every day and get up at 11 , while for someone else it can mean something totally different. We're all different as human beings. (Local authority official)

What was assumed to be 'totally different' was not stated in the interview, but the example seems to suggest that it could be 'eating pizza every day and getting up at 7'. A representation of good care as subjective and related to preferences could indeed encompass anything that makes the individual content. At the same time, the choice discourse tended to silence aspects such as available time, personal care and care relationships. Following from this, the representation of care was disconnected from aspects such as getting enough home care hours to meet one's needs, getting help to shower or to go to the toilet, or getting to know the care worker.

The informants usually referred to 'older people' in their accounts of home care but, within the choice discourse, older people were also constructed as subjects in 
terms of 'customers'. As customers and consumers, older people were represented as having more power over their daily life. One representative of SPF envisioned a care market where 'the customer' can approach potential care providers asking: 'Here are my home care hours, what can you offer me?' Hence, in the account of this informant, the implementation of choice in home care was represented as empowering individuals. Providers could now offer services beyond standard needs-assessed home care, e.g. 'extra outdoor activities' or 'delivering a specific brand of wine'. Again, care was associated with preferences, rather than needs. References such as getting a specific brand of wine connect care to social class, given that this preference can be associated with the lifestyle of older people belonging to the middle (or upper) class. The other representative of the same organisation also strongly put forward a choice discourse, but had some doubts about the capacity of older people with care needs to act as empowered care consumers: 'I don't think we like to present ourselves once we need home care, many cannot speak for themselves.' The assumption of individual autonomy was indeed also challenged at times by the informants who articulated a choice discourse.

In the choice discourse, the notion of equality was largely absent. The silence on inequalities also became evident in accounts on private domestic services (RUT). Some informants attributed vital meaning to privately purchased services in their perception of good care and the future of the home care system. This included the key bearers of the choice discourse previously mentioned, but only one of the six local authority officials. 'Topping-up' was framed as a way for individuals to get the care they want and to continue habits and lifestyles, such as going out to eat at a specific place, even at the age of 90. Emphasising individual freedom and self-determination, these accounts never mentioned class-related inequalities. As such, buying additional services was represented as a choice that all older people have. A couple of informants framed equality as a problem, constructing equality as sameness and criticising that all older people are treated the 'same way' in spite of their diversity and different preferences. For example, one representative of SPF said that: 'still, one has lived an individual life for 80 years or so, perhaps. And then, suddenly, [one] is to get the same as everyone else'. Further, one right-wing politician constructed home care as a 'budget alternative' and argued that 'we' should accept that some people top-up their home care and thereby get a higher standard of living. By highlighting diversity, equality was constructed as a problem:

Although we now say that we're all different and there should be diversity and people have different needs, care should be dignified and there should be good treatment and those things. While saying these things, some get furious if it's different, if people get unequal care. Then some automatically react like: 'in that case everyone should do equally bad', rather than letting some do a little bit better. (Politician)

This way the choice discourse was articulated as conflicting with a negative notion of equality. In contrast, the choice discourse presented here was often combined with a needs discourse in the interviews. In the following, we outline and analyse the central elements of the needs discourse. 


\section{The needs discourse}

The great majority of the informants included in the study articulated a needs discourse. Thus, most of the informants who constructed home care with reference to choice also articulated a needs discourse. Other informants primarily articulated a needs discourse, and to a much lesser extent a choice discourse. These latter informants include the representatives of the Senior Citizen Council of Stockholm, the senior citizens' organisation PRO, the Municipal Workers Union, the Association of Non-profit Health and Social Service Providers and left-wing political representatives. The Social Services Act was the legal reference in this discourse.

In the needs discourse, home care was framed in terms of the public elder-care system, which has changed significantly in recent decades. Asked questions about day-to-day practices of home care and the organisation of services and care work, many emphasised that the characteristics of home care recipients have also changed. The needs discourse often constructed older people with home care as 'users' and it was pointed out that users today generally are very ill and have great care needs, many of them suffer from dementia and some need health care at home. The informants pointed out that people who, in the past, would have been cared for in nursing homes are now living at home with extensive home care, including both day and night care. In this context, the majority of the informants argued that the ageing-in-place principle in elder-care has gone 'too far'. They also stated that the boundaries between social care and health care have become blurred. With older people now represented as users with great care needs, needs were located at the intersection of social and nursing care. In this context, care was related to available time: that the home care hours are enough to get one's needs met without generating too much stress.

When the informants discussed the changing elder-care system, good home care was represented differently than in the accounts related to the implementation of choice. Care workers were now attributed a central role in good care. In view of the current home care system, which targets those with the greatest care needs, the informants generally shared the perception that care work in the home care sector has changed significantly. Care work in the sector was described as a 'very difficult' and 'demanding' job and was contrasted with the common perception that 'anyone can do it'. For example, one left-wing politician underlined that many people who participate in the public debate on home care mistakenly believe it is about 'going to Agda's ${ }^{4}$ and making some coffee'. Another issue raised by many informants was that home care workers assist not only older people with great care needs, but also older people affected by psycho-social problems. Home care users include older people with alcohol problems and mental health problems. One representative of a right-wing party described this development:

Well, in the past addicts, for example, died. Now they survive - we're happy about that of course - and they get older and need elder-care. Similarly, in the past many people with mental health problems were institutionalised, which wasn't good, but now they're here, and home care must deal with both addiction and mental health problems. So, this is really a different profession. (Politician) 
The focus typically fell on care workers' education, qualifications and professionalism. Moreover, in the needs discourse, language was connected to getting one's needs fulfilled. Not only foreign languages were highlighted but also the requirement that care workers have sufficient knowledge of Swedish. Care workers were largely attributed responsibility for providing good care at an individual level, but some informants also underlined that the system needs to enable care workers' discretion. The representatives of the trade union and PRO emphasised that good care requires good working conditions, but this idea was not central in other interviews. The concept 'continuity' was mentioned as important for older people, which related to the problem of receiving help from numerous different care workers. However, aspects such as social needs and care relationships-established between care recipients and care workers - were usually not emphasised.

While many informants shifted back and forth between the choice and the needs discourses, some represented these as conflicting. Then, the great vulnerability of home care users was represented as contesting a key assumption of the choice discourse, namely the idea of older users as relatively autonomous individuals who can simply choose a new provider if they do not get good - or adequate - care. For example, the representative of the Municipal Workers Union reported:

When it is about very weak persons who are in very vulnerable positions, like older people often are ... or, they are! Then it's not like you say: 'oh, I got a bad banana', I bought it at Konsum, so I'll go to Ica [Swedish supermarkets]. It's not that easy. It's about human relationships and trust and those things. And people who are ill many times, who cannot easily vote with their feet. And it's about their lives, that they're well cared for ... Like, 'they should vote with their feet but instead they died', or got a wound that ... if you're going to bring this matter to a head. (Municipal Workers Union representative)

Although 'user influence' in daily care was mentioned, the informants seldom elaborated on the meaning of the concept. In contrast to the active consumers of the choice discourse, the needs discourse tended to represent older people with home care as passive, as recipients of help and support. In this subject position, older people with home care did not have a central role in defining good care.

There was sometimes a tension in the discourse between the focus on meeting the care needs of an ageing population and an emphasis on economic constraints, not least in relation to future elder-care. Politicians of left- and right-wing parties, local authority officials and representatives of interest organisations emphasised economic problems. They generally stressed that care for older dependent people requires (too) many resources. As such, the ageing population was assumed to represent a 'problem' for the welfare state. Whereas many informants highlighted that ageing-in-place has gone too far, many also underlined that 'not everyone can get a place in a nursing home'. Altogether, the reorganisation of home care was constructed as a crucial question for the future. There was convergence in the view that a reorganisation will be necessary, both for greater economic efficiency and for meeting the needs of the ageing population. The representative of the Swedish Association of Local Authorities and Regions underlined that the 
key challenge is how to reorganise the home care system in order to manage both health and social care provision in the home 24/7:

Older people manage by themselves more and more and they are healthier. But when you get to a point where you need help, then you need quite a lot of help. You need a lot of home care, you need a lot of home nursing. It's this context that I think we should debate ... People choose RUT instead of home care, if they only need that [domestic services]. So it's more about care and nursing care; how can this be organised so that we can manage: 24 hours, 7 days a week, 365 days a year? (SKL representative)

In this account, the targeting of the frailest elderly in future home care was taken for granted, and thereby the exclusion of older people with smaller care needs was legitimised. In this vein, in some interviews, needs were defined by distinguishing between the more important basic needs related to personal and nursing care, and other less-urgent needs related to, for example, having a clean home. The assumption of an economically unsustainable elder-care system was common in the interviews, and for some informants this idea motivated a re-negotiation of public responsibility. This was clearly articulated in the interview with the two representatives of SPF. They described their ideas of future home care in the following way:

I1: I think they [RUT services] will become more and more important in the future $\ldots$ because of a development where maybe society, the municipality, will only offer health and care services in the home. And things like cleaning you'll have to arrange in another way, because that's not a public responsibility to deal with.

I2: ...and you're not equally dependent on keeping away the dust as on getting your medicine. (SPF representatives)

Drawing on the assumption that older people's needs can and should be divided into more important needs and less-pressing ones, future home care was articulated as requiring a strict separation between domestic tasks, provided by unskilled workers, and care - including personal care and nursing tasks - performed by qualified staff. Domestic tasks were here defined as different from care, even when performed in the home of an older person dependent on help and support in daily life. Apart from the economic reasoning, the development described was also justified by referring to the lack of qualified care workers. In contrast, the representative of the Association of Private Care Providers emphasised that since RUT services are offered by private home care companies, the same staff can provide needs-assessed care and private out-of-pocket domestic services. The representative framed this as supporting continuity and hence as positive from the older people's perspective:

I know that among older people there's often the perception that the needs assessment is too strict. Like, you didn't get what you felt you needed. And then it's positive that you can buy extra services, but you get it provided by the same personnel that you already have, given that continuity is something many older people 
demand. So if you're to take older people as the starting point, it's positive that there's this possibility. (Association of Private Care Providers representative)

The quote refers to unfulfilled needs, but austerity and strict needs assessments are not primarily problematised here. The informant focused on the individual's opportunity to buy additional services, and thereby fill the gap between their perceived needs and the services granted. Here the needs discourse overlaps with the choice discourse: older people are represented as having the choice to top up their home care to get their needs fulfilled. Overall, as in the choice discourse, social inequalities were absent in the needs discourse.

\section{The equality discourse}

The equality discourse was a rather marginal discourse in the interviews. Equality was generally not mentioned by the informants when they were asked about the implementation of choice in home care. In a few interviews, equality was an issue raised in relation to the questions about fulfilling older people's needs and good care. The equality discourse was mainly articulated by the two representatives of PRO and the representative of the Association of Non-profit Health and Social Service Providers (Famna). As in the needs discourse, the legal reference was the Social Services Act.

In the equality discourse, the institution of home care was framed as a universalistic care system. A subject position that was absent in most accounts was made available here as older people with home care were constructed as 'citizens'. Subsequently, care was framed in terms of citizen rights and there was a concern about inequalities in care. The informants emphasised the egalitarian ambitions of the Swedish welfare state by stressing that home care is a public responsibility and that all older people have the right to have their needs fulfilled - and to receive good care. Overlapping with the needs discourse, equality was linked to the idea that needs, not the ability to pay, must determine the distribution of care. Class and gender inequalities were brought up, pointing at the situation of 'poor pensioners', and especially women with small incomes. For example, one PRO representative stressed that good care must be equal:

Good care, it must be on equal terms, so it must be equal. That's really important. Everyone has the right to receive good care, that's just how the welfare system should be designed. And it should not be based on capacity to pay or so, that's very important for PRO because we represent so many with low pensions also. And they should have access to good care. Women, 150,000 poor pensioners, mainly women. And they call me and tell me: 'oh, now they have increased this home care fee again, I can't afford it!' (PRO representative)

The informants who articulated the equality discourse were concerned about the expansion of privately purchased services among older people. It was argued that the publicly funded care system must guarantee all older people good and dignified care; and hence additional private out-of-pocket services should not be necessary. The other representative of PRO underlined that if older people have to 
complement their care with privately purchased services, this development 'undermines everything that the Social Services Act stands for'.

The representative of the Association of Non-profit Health and Social Service Providers pointed out that rather than supporting a market of private for-profit care companies, policies should promote non-profit care providers. In this account, the distinction between for-profit and non-profit care provision was articulated as central for good care. The informant emphasised that when non-profit providers see that the public resources are not sufficient to meet the needs of individual citizens, they try to find ways to cover the gap, using extra resources within the organisation if necessary. It was argued that non-profit providers put 'citizens' wellbeing' in the centre, not 'business'. The representative reported on non-profit care providers:

These actors are driven by the gap they see and want to fill, and not by doing business. So then, often the idea would be ... if they think what's included in the public arrangement is not enough to meet the needs of the individual, then the idea would be to work to achieve that. And it's not so often they focus on the most well-to-do, it's not really there you see the problems. (Famna representative)

Concurrently, the representative emphasised the role of non-profit care providers in meeting the needs of older citizens, not least the need of less-privileged groups. The informant contrasted this with enabling (some) older people to top up their needs-assessed home care through RUT. Moreover, one local authority official articulated an equality discourse, but adopted a different perspective than the other informants mentioned here. This official argued in favour of targeting the poor given economic inequalities and economic constraints in elder-care:

Elder-care has a deficit. We don't have money for everything and so one could think like: well, if you can afford to buy more ... I think that if you can afford to buy more then you should. We should target; you are not allowed to say this, but there are differences in incomes, we can't ignore that. Then we need to help first of all those who can't buy this [help], I think. (Local authority official)

Hence, the informant argued that those who can afford it should top up their needs-assessed care because this way resources could primarily be directed at older people with lower incomes. The claim for targeting the poor was linked to an assumption of elder-care as economically unsustainable and to the projected growth in demand coming with population ageing. This idea stood in tension with the emphasis on good care for all older people within the framework of the universalistic model.

\section{Discursive struggles about defining home care: contrasts and conflicts}

Three competing discourses have been identified and analysed: the choice, needs and equality discourses. Table 2 summarises key elements of the discourses, focusing on the subject positions attributed to older people with home care, the meanings ascribed to (good) care, and central concepts and assumptions associated with home care as a system. Tensions within each discourse are also included. 


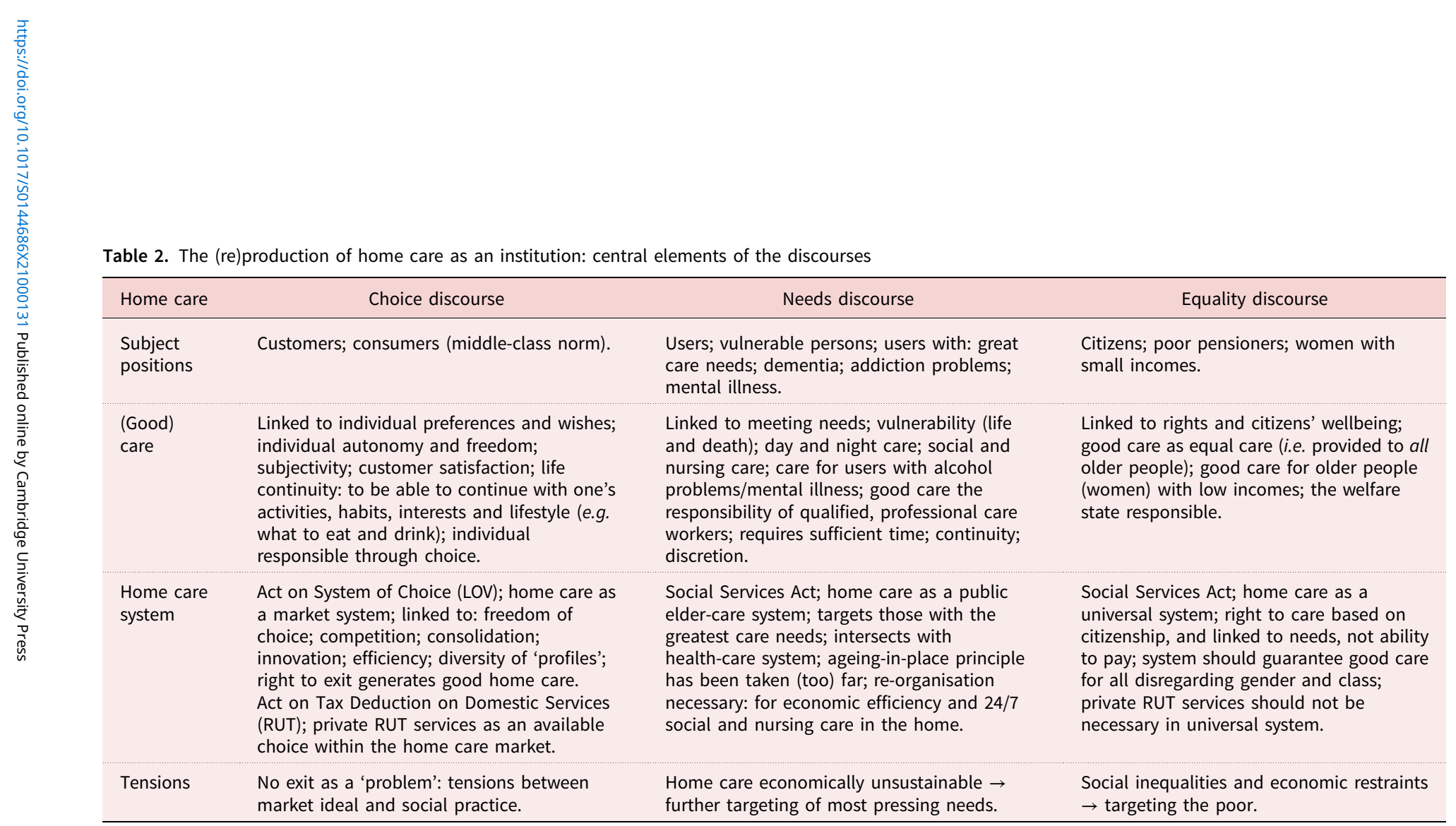


The three discourses on choice, needs and equality are not necessarily contradictory, but definitely entail very different narratives of home care. Each discourse is internally coherent with respect to the articulation of subjects, meanings of (good) care and the framing of home care as a system. However, this coherence was not evident in the informants' accounts. Although the choice and the needs discourses entail quite different representations of home care - and older people who receive it - many of the interviews combined elements of both discourses. For example, when asked about the implementation of choice in home care, informants articulated a choice discourse, and when asked about the organisation of daily care, they turned to a needs discourse. In contrast, no informant drew on both choice and equality discourses in their talk about home care.

The discourses made available different subject positions. The most common subject position was indeed 'older people'. Nevertheless, there were significant differences between the discourses: in the choice discourse older people were sometimes constructed as 'customers', the needs discourse highlighted vulnerable persons and 'users' with great care needs, and the equality discourse constructed older people as 'citizens'. None of the informants articulated older people with home care as both 'customers' and 'citizens' in their accounts on home care. This conflict can be related to normative assumptions about class; the choice discourse assumed a middle-class norm while the equality discourse highlighted the problem of class and gender inequalities.

The discourses on home care also attributed different meanings to care, and assigned responsibility for ensuring care was good to different actors. In the choice discourse, care was represented as a subjective experience, linked to the individual preferences and wishes of older people, who were responsible through their choices for the quality of care they received. Good care was associated with being able to continue activities, habits, interests and lifestyle also in old age, while vulnerability and needs were downplayed. Through specific examples, care was associated with a middle-class norm. In the needs discourse, focus fell on meeting the needs of very vulnerable persons with great care needs, many requiring health care at home and some affected by alcohol addiction or mental illness. Care workers were assigned primary responsibility for ensuring that care was good, but while their qualifications, professionalism, language skills, etc., were emphasised, social and relational aspects of care were seldom in focus. Older people with home care were generally attributed a passive role, also in the definition of good care. In the equality discourse, care was associated with citizenship rights and the wellbeing of senior citizens. This discourse emphasised that good care should be equal, provided to all citizens, not just to those who belong to the privileged classes. In the equality discourse, the welfare state was responsible for equal access to good care.

Home care as a system was constructed differently in the discourses; as a market system in the choice discourse, as a public elder-care system in the needs discourse and as a universal system in the equality discourse. The choice discourse highlighted concepts associated with the market, such as freedom of choice, competition, innovation and efficiency. Diversity of 'profiles' was described as producing care tailored to individual preferences. The right to 'exit' was constructed as the key to achieving good care at both individual and system levels, although in tension with the recognition that, in practice, older people seldom change providers. Private 
RUT services were framed as an available choice within the home care market. The needs discourse highlighted that the public elder-care system has gradually targeted those with greatest care needs and, consequently, social care increasingly intersects with the health-care system. The ageing-in-place principle was represented as a problem in this context. Many informants considered a future reorganisation of home care was necessary to manage $24 / 7$ care in the home but also to increase economic efficiency. There was a tension within the discourse related to the assumption that Swedish elder-care lacks economic sustainability. Based on this assumption, some informants promoted further targeting of the most 'important' needs, contrasting, for example, nursing care with domestic tasks. In the equality discourse, the home care system was linked to the universalistic welfare state. It was emphasised that needs not ability to pay (e.g. for RUT services) should determine the care older people receive and that all older people have the right to receive good care. A tension within the equality discourse involved the idea of targeting the poor, highlighting income inequalities and drawing on the assumption of an economically unsustainable home care system.

\section{Concluding discussion}

This article takes an understanding of institutions as contested and open-ended formations as the point of departure (Bacchi and Rönnblom, 2014). In this vein, home care is seen as an institution constituted through ongoing discursive struggles (Vabø, 2015). Drawing on interviews with key informants, engaged in policy making, implementation or advocacy related to care for older people, the analysis highlights three discourses that shape the articulation of home care in the Swedish context. The choice discourse constructs relatively autonomous older adults with smaller care needs as subjects and highlights life continuity in habits and lifestyle, but it silences vulnerability as well as social inequalities. The needs discourse, in contrast, constructs very vulnerable older adults with great care needs as subjects and situates care in the nexus of health and social care. The widely adopted assumption of home care as economically unsustainable generates a tension within as it connects with ideas about further targeting of the 'most important' needs. The equality discourse is less prevalent in our data, but it highlights that all senior citizens should receive good care and it conflicts with the choice discourse in the assumptions about class.

Limitations to this study are recognised. The number of informants is limited and it is possible that a wider selection of actors would reveal other aspects and meanings. Discourses on home care are context-bound and the framing of the bigger study, focusing on the implementation of choice in home care in Stockholm, is likely to have shaped the issues raised and the relative importance of the different discourses in the data. Nonetheless, we argue that the results can be generalised at an analytical level, as they can contribute to our understanding of the discourses that shape the institution of home care, their tensions, conflicts and silences. Our findings also align with the results of interview and policy studies that analyse how the choice discourse (connected with a market discourse) legitimises certain ways forward in Swedish social care (e.g. Nilsson et al., 2018; Lindberg and Lundgren, 2019). Elder-care is the subject of renewed public attention in the context of the COVID-19 pandemic and it is important to explore the way home care is 
being framed. Future studies could fruitfully explore the extent to which dominant discourses silence equality and legitimise a shift in public responsibility within the Nordic 'universalistic' care regime. Discourses matter, not least because they provide the narrative(s) that can frame key questions for future home care. By contrasting discourses, we highlight the politics involved in (re)creating home care as an institution.

Acknowledgements. The authors wish to thank Gabrielle Meagher and Marta Szebehely for very helpful comments on different versions of the article. Thank you also to the anonymous reviewers for valuable comments.

\section{Author contributions.}

Both authors have made a substantial contribution to the design, analysis and drafting of the article.

Financial support. This work was supported by the Swedish Research Council for Health, Working Life and Welfare (Forte), within the project 'Sustainable care in a customer choice model? Dilemmas and possibilities of small homecare enterprises' (Dnr 2014-4913); the research programme 'Individualised care and universal welfare: dilemmas in an era of marketization' (Dnr 2013-2296); and Nordforsk ('Social inequalities in ageing' project). Funding bodies have played no role in the design, execution, analysis and interpretation of data.

Conflict of interest. The authors declare no conflicts of interest.

Ethical standards. The study was approved by the the Regional Ethical Vetting Board in Stockholm (Dnr 2015/1510-31/5).

\section{Notes}

1 About 85 per cent of elder-care expenditure comes from municipal tax (Szebehely and Trydegård, 2012). 2 There is a maximum user fee established at the national level: 2,125 SEK per month for 2020 (approximately €200).

3 Taxpayers can deduct 50 per cent of domestic services up to 75,000 SEK $(€ 7,300)$ per person per year (from 1 Jan. 2021). RUT is the acronym for Cleaning, Maintenance and Laundry in Swedish (Rengöring, Underhåll, Tvätt), but the tasks that can be included have been expanded since the introduction in 2007.

4 A Swedish female name currently associated with the older generation.

\section{References}

Aldén L and Hammarstedt M (2014) Integration of Immigrants on the Swedish Labour Market-Recent Trends and Explanations (Report No. 2014:9). Växjö, Sweden: Labour Market and Discrimination Studies, Linnæus University.

Andersson K and Kvist E (2015) The neoliberal turn and the marketization of care: the transformation of eldercare in Sweden. European Journal of Women's Studies 22, 274-287.

Anttonen A (2005) Empowering social policy: the role of social care services in modern welfare states. In Kangas O and Palme J (eds), Social Policy and Economic Development in the Nordic Countries. London: Palgrave Macmillan, pp. 88-117.

Bacchi C (2005) Discourse, discourse everywhere: subject 'agency' in feminist discourse methodology. NORA - Nordic Journal of Feminist and Gender Research 13, 198-209.

Bacchi C and Rönnblom M (2014) Feminist discursive institutionalism - a poststructural alternative. NORA - Nordic Journal of Feminist and Gender Research 22, 170-186.

Barnes M and Prior D (1995) Spoilt for choice? How consumerism can disempower public service users. Public Money \& Management 15, 53-58.

Béland D (2016) Ideas and institutions in social policy research. Social Policy \& Administration 50, 734750 . 
Béland D and Powell M (2016) Continuity and change in social policy. Social Policy \& Administration 50, 129-147.

Brennan D, Cass B, Himmelweit S and Szebehely M (2012) The marketisation of care: rationales and consequences in Nordic and liberal care regimes. Journal of European Social Policy 22, 377-391.

Brodin H (2017) Still a responsive state? Marketization and inequalities in Swedish aged care. In Fineman $\mathrm{M}$, Andersson U and Mattsson T (eds), Privatization, Vulnerability and Social Responsibility: A Comparative Perspective. London: Routledge, pp. 201-220.

Burau V, Zechner M, Dahl HM and Ranci C (2016) The political construction of eldercare markets: comparing Denmark, Finland and Italy. Social Policy \& Administration 51, 1023-1041.

Clarke J (2006) Consumers, clients or citizens? Politics, policy and practice in the reform of social care. European Societies 8, 423-442.

Dunér A, Bjälkebring P and Johansson B (2019) Merely a rhetorical promise? Older users' opportunities for choice and control in Swedish individualised home care services. Ageing \& Society 39, 771-794.

Erlandsson S, Storm P, Stranz A, Szebehely M and Trydegård GB (2013) Marketising trends in Swedish eldercare: competition, choice and calls for stricter regulation. In Meagher G and Szebehely M (eds), Marketisation in Nordic Eldercare: A Research Report on Legislation, Oversight, Extent and Consequences (Stockholm Studies in Social Work 30). Stockholm: Department of Social Work, Stockholm University, pp. 23-84.

Fotaki M and Boyd A (2005) From plan to market: a comparison of health and old age care policies in the UK and Sweden. Public Money \& Management 25, 237-243.

Glendinning C (2008) Increasing choice and control for older and disabled people: a critical review of new developments in England. Social Policy \& Administration 42, 451-469.

Laclau E and Mouffe C (2001) Hegemony and Socialist Strategy: Towards a Radical Democratic Politics. London: Verso.

Lindberg J and Lundgren AS (2019) Positioning the ageing subject: articulations of choice in Swedish and UK health and social care. Policy Studies, DOI:10.1080/01442872.2019.1599839.

Meagher G and Szebehely M (2010) Private financing of elder care in Sweden. Arguments for and against. Institute for Future Studies, Stockholm, Working Paper 2010: 1.

Meagher G and Szebehely M (2019) The politics of profits in Swedish welfare services: four decades of Social Democratic ambivalence. Critical Social Policy 39, 455-476.

Meinow B, Parker MG and Thorslund M (2011) Consumers of eldercare in Sweden. The semblance of choice. Social Science and Medicine 73, 1285-1289.

Ministry of Finance (2020) En gemensam angelägenhet [A Common Concern] (SOU 2020:46). Stockholm: Ministry of Finance.

Moberg L (2017) Marketisation of Nordic eldercare - is the model still universal? Journal of Social Policy 46, 603-621.

Moberg L, Blomqvist P and Winblad U (2016) User choice in Swedish eldercare -conditions for informed choice and enhanced service quality. Journal of European Social Policy 26, 281-295.

National Board of Health and Welfare (NBHW) (2019a) Statistik om äldre och personer med funktions-nedsättning efter regiform 2019 [Statistics on Older People and People with Impairments According to Provider Type 2019]. Available at https://www.socialstyrelsen.se/statistik-och-data/statistik/statistikamnen/socialtjanstinsatser-till-aldre-och-personer-med-funktionsnedsattning-efter-regiform/.

National Board of Health and Welfare (NBHW) (2019b) Statistik om socialtjänstinsatser till äldre 2019 [Statistics on Social Services for Older People 2019]. Available at https://www.socialstyrelsen.se/statistikoch-data/statistik/statistikamnen/socialtjanstinsatser-till-aldre/.

National Board of Health and Welfare (NBHW) (2020) Vård och omsorg om äldre: Lägesrapport 2020 [Health and Social Care for Older People: Progress Report 2020]. Stockholm: NBHW.

Nilsson M, Jönson H, Carlstedt E and Harnett T (2018) Nursing homes with lifestyle profiles - part of the marketisation of Swedish eldercare. International Journal of Care and Caring 2, 49-63.

Rostgaard T (2012) Quality reforms in Danish homecare - balancing between standardization and individualization. Health and Social Care in the Community 20, 247-254.

Schmidt V (2008) Discursive institutionalism: the explanatory power of ideas and discourse. Annual Review of Political Science 11, 303-326.

Sivesind KH (2017) The changing roles of for-profit and nonprofit welfare provision in Norway, Sweden, and Denmark. In Sivesend KH and Saglie J (eds), Promoting Active Citizenship Markets and Choice in Scandinavian Welfare. London: Palgrave Macmillan, pp. 33-74. 
SKR (2019) Kommunernas valfrihetssystem-beslutsläge april 2019 [Local Freedom of Choice Systems. Decision Status April 2019]. Available at https:/skr.se/demokratiledningstyrning/driftformervalfrihet/ valfrihetssystemochersattningsmodeller/socialomsorg/valfrihetssystemikommunerbeslutslaget2019.

29749.html.

Statistics Sweden (2019) Anställda (yrkesregistret) 16-64 år efter Yrke (SSYK 2012), födelseregion, kön och år [Employees (Occupational Register) 16-64 Years by Occupation (SSYK 2012), Region of Birth, Sex and Year]. Stockholm: Statistics Sweden.

Szebehely M and Meagher G (2018) Nordic eldercare - weak universalism becoming weaker? Journal of European Social Policy 28, 294-308.

Szebehely M and Trydegård GB (2012) Homecare in Sweden: a universal model in transition. Health and Social Care in the Community 20, 300-309.

Ulmanen P and Szebehley $\mathbf{M}$ (2015) From the state to the family or to the market? Consequences of reduced residential eldercare in Sweden. International Journal of Social Welfare 24, 81-92.

Vabø M (2006) Caring for people or caring for proxy consumers. European Societies 8, 403-422.

Vabø M (2015) Changing welfare institutions as sites of contestation. In Engelstad F and Hagelund A (eds), Cooperation and Conflict the Nordic Way: Work, Welfare and Institutional Change in Scandinavia. Berlin: De Gryter Open, pp. 243-261.

Vabø M and Szebehely M (2012) A caring state for all older people? In Anttonen A, Häikiö L and Stefansson K (eds), Welfare State, Universalism and Diversity. Cheltenham, UK: Edward Elgar, pp. 121-143.

Vamstad J (2016) Exit, voice and indifference - older people as consumers of Swedish home care services. Ageing \& Society 36, 2163-2181.

Cite this article: Peterson E, Brodin H (2022). Choice, needs or equality? Discursive struggles about defining home care for older people in Sweden. Ageing \& Society 42, 2433-2453. https://doi.org/10.1017/ S0144686X21000131 